\title{
Detection and molecular characterisation of bovine corona and toroviruses from Croatian cattle
}

\author{
Ivana Lojkić ${ }^{* \dagger}$, Nina Krešić ${ }^{\dagger}$, Ivana Šimić and Tomislav Bedeković
}

\begin{abstract}
Background: Bovine coronavirus ( $\mathrm{BCOV}$ ) together with bovine torovirus (BToV), both members of the Coronaviridae family, order Nidovirales are the most common viral enteric pathogens. Although studied separately, their joint occurrence and the molecular diversity in cattle in Croatia have not been investigated.

Methods: A survey is carried out on 101 fecal samples from diarrheic young and adult cattle during the 3-year period from i) one large dairy herd, ii) four small herds and iii) three nasal and paired fecal samples from calves with symptoms of respiratory disease. Samples were submitted to RT-PCR and sequencing for BCoV Nucleocapsid gene, BCoV Spike gene and BToV Spike gene.

Results: BCoV was detected in $78.8 \%$ of fecal samples from symptomatic cattle and three nasal and paired fecal samples from calves with respiratory symptoms. BToV was detected in $43.2 \%$ of fecal samples from symptomatic cattle and a fecal sample from calves with respiratory symptoms. Molecular characterisation of those viruses revealed some nucleotide and aminoacid differences in relation to reference strains.
\end{abstract}

Conclusions: BToV should be regarded as a relevant pathogen for cattle that plays a synergistic role in mixed enteric infections.

Keywords: BCoV, BToV, Nucleocapsid, Spike, Phylogenetic analysis

\section{Background}

Diarrhea is an important disease affecting cattle worldwide. Together with the Bovine rotavirus (BRoV), bovine coronavirus $(\mathrm{BCoV})$ and bovine torovirus $(\mathrm{BToV})$, both members of the Coronaviridae family, order Nidovirales [1] are the most common viral enteric pathogens. They both cause diarrhea and respiratory-tract infections in calves as well as in adult cattle [2-5].

Coronaviridae members are enveloped viruses with non-segmented positive-sense single stranded RNA genome [6]. These viruses share the same basic genome organization and similar replication strategies. However, there are marked differences in genome size, host range, and virion architecture $[1,7]$ and there is no antigenic relationship between these two viruses. The virions of

\footnotetext{
* Correspondence: ilojkic@veinst.hr

${ }^{\dagger}$ Equal contributors

Department of Virology, Croatian Veterinary Institute, Savska cesta 143, 10000, Zagreb, Croatia
}

corona and toroviruses contain four and five structural proteins, respectively: the spike $(S)$, the membrane $(M)$, the haemagglutinin-esterase (HE) protein, the nucleocapsid $(\mathrm{N})$ protein and the small envelope $(\mathrm{E})$ protein [8]. The latter is not present in toroviruses. Another specificity of some coronaviruses is the internal nucleocapsid ORF coding for I protein [9]. Variations in host range and tissue tropism of coronaviruses are attributed to the spike (S) glycoprotein [10]. This protein is cleaved by an intracellular protease into two functional domains [10]. The peripheral S1 subunit is responsible for virus binding to host-cell receptors [11], induction of neutralizing antibodies [12], and haemagglutination activity [13]. The S1 sequence is variable, mutations in this region have been associated with altered antigenicity and virus pathogenicity [14] and this region has been exploited as a target to study the molecular epidemiology of $\mathrm{BCoV}$ infection $[15,16]$. The sequence of the $\mathrm{S} 2$ subunit is more conserved and this subunit is responsible for cell membrane fusion activity [17]. 
$\mathrm{BCoV}$ infection has a high morbidity but a low mortality and is found worldwide among cattle of all ages [6]. Outbreaks typically occur in autumn and winter [18, 19]. Economic losses can be heavy due to a marked reduction in milk yield [20, 21].

$\mathrm{BToV}$, formerly called Breda virus, was originally isolated from diarrheic calves in Breda, Iowa, in 1979. Until today, BToV was described in diarrhoeic calves in various countries $[4,2,22-26,27]$. The faecal prevalence of BToV in calf diarrhea ranges from $2.9 \%$ in South Korea [25] to $36.4 \%$ in southern Ontario, Canada [22].

There are no available published data about the viral agents that are involved in calf diarrhea, although reports of the farmers complaining in calf diarhhea are very often. In this work we investigated fecal samples of cattle from one large dairy herd and from four small farms during the 3 -year period. We also characterised nasal and paired fecal samples from calves with symptoms of respiratory disease. So for the first time, the occurrence and the molecular phylogeny of BCoVs and BToVs in selected herds from Croatia are assessed.

\section{Methods}

\section{Ethics statement}

This statement confirms that sampling for the purpose of this research was performed as non experimental clinical work with respecting the rules of veterinary profession. All samples were collected by veterinarian Nina Krešić, license number 2202. Sampling was performed strictly on the owner request. This statement is an annex to Ethical Committee permission of Veterinary Faculty University of Zagreb; number: 251-61-01/139-11-72.

\section{Samples}

Fecal samples from 101 diarrheic animals were collected from March 2010 to May 2012. Samples originated from calves and adult cattle from one large dairy herd (designated as "B") in eastern Croatia $(N=65)$ and four small family farms in Central Croatia (designated as "K"), all mixed dairy-beef production $(N=35)$. Three nasal swabs were collected in 2011 in east Croatia from calves showing respiratory symptoms (designated as " $\mathrm{D}$ "). A paired pooled fecal sample was taken from the same calves. All sampled cattle were showing clinical signs of enteric infection except those designated as D71-D73 where respiratory signs were present. Fecal samples were diluted 1:10 in minimal essential medium ( $\mathrm{pH}$ 7.4; Life Technologies, USA) with addition of $1 \%$ Antibiotic Antimycotic Solution (SigmaAldrich). Suspensions were centrifuged at $12,000 \mathrm{~g}$ for 15 min at $4{ }^{\circ} \mathrm{C}$ and only the supernatants were used in the assays. All fecal samples were also tested by RT-PCR for rotavirus-A [27]. Nasal samples were tested by PCR/RTPCR for bovine herpes virus type 1 (BHV-1) [28], bovine respiratory syncytial virus (BRSV) [29], bovine parainfluenza virus type 3 (BPIV-3) (in-house method) and bovine viral diarrhea virus (BVDV) [30].

\section{CDNA synthesis and PCR}

Viral RNA was extracted from samples using QIAamp Viral RNA (QIAGEN, Hilden, Germany), according to manufacturer's instructions. cDNA synthesis were performed with Moloney-Murine leukaemia virus reverse transcriptase (M-MLV RT) (Invitrogen, USA) and random primers $(50 \mathrm{ng} / \mathrm{lL})$ (Invitrogen) in a $20 \mathrm{uL}$ final reaction volume. The cDNA of each sample was screened for the $\mathrm{BCoV}, \mathrm{BToV}$ and $\mathrm{BRoV}-\mathrm{A}$ genome using the primers described in Table 1. PCR reactions were performed using GoTaq $^{\text {Tm }}$ Green Master Mix (Promega, USA), according to manufacturer instructions. A total of 16 samples were chosen for sequencing; all samples were sequenced for partial $\mathrm{BCoV} \mathrm{N}$ and $\mathrm{S}$ gene, and five of these samples were sequenced for BToV $\mathrm{S}$ gene as well. Eight samples were from large dairy farm in eastern Croatia (B27/10, B30/10, B32/11, B37/11, B3492/11, B34649/11, B60853/11, B6075/ 12); four samples were from small family farms in Central Croatia (K12/10, K658/10, K5220/11, K6578/11), and four from calves with respiratory symptoms (D71-D73F). Amplified PCR products were purified using Exosap (USB, Staufen, Germany) and direct sequenced using the PCR primers in both directions by Macrogen Inc. (Seoul, Korea). Nucleotide sequences generated in this study have been submitted to GenBank and were assigned the following accession numbers as listed in Table 2.

\section{Sequence alignment and phylogenetic analysis}

Sequences were aligned and compared to previously published $\mathrm{BCoV} \mathrm{N}, \mathrm{BCoV} \mathrm{S}$ and $\mathrm{BToV} \mathrm{S}$ sequences, respectively. Sequence identities of nucleotides as well as estimation of the evolutionary divergence between sequences were analyzed using BioEdit and Mega6 [31] software, respectively. The neighbour-joining (NJ) trees were obtained using Mega6 program with the evolutionary model set to Tamura-Nei + Gamma for Spike gene analysis and Kimura-2 parametar for $\mathrm{N}$ gene. Estimation of best-fit model by hierarchical likelihood ratio tests (hLRTs) and approximate Akaike information criterion (AIC) was performed with jModelTest V.0.1.1. [32]. Reliabilities of phylogenetic relationships were evaluated using nonparametric bootstrap analysis with 1000 replicates for NJ analysis. Bootstrap values exceeding 70 were considered well supported.

The dataset included the reference strains of $\mathrm{BCoV}$ : Mebus (GenBank accession number U00735), Quebec (AF220295) respiratory BCoV strains: LSU2 (AF058943), OK-3 (AF058944) and AH187 (FJ938065); Italian strains 179/07-11 (EU019216), 438/06-TN (EU814647) and 339/ 06 (EF445634); Korean strain KWD19 (DQ389660), Japanese strain Kakegawa (AB354579), Swedish strain SWE/ 
Table 1 Oligonucleotide primers for PCR and sequencing reaction

\begin{tabular}{|c|c|c|c|c|}
\hline PRIMER NAME & SEQUENCE $\left(5^{\prime} \rightarrow 3^{\prime}\right)$ & SIZE (bp) and location of amplicon & GENOME POSITION $^{\mathrm{a}}$ & REFERENCE \\
\hline $\mathrm{BCoV} F$ & CCGATCAGTCCGACCAATC & 460 & $29476-29494$ & {$[46]$} \\
\hline $\mathrm{BCoV} R$ & TAGTCGGAATAGCCTCATCGC & BCoV N gene & 29899-29919 & \\
\hline S-S1 & GATAAGTTTGCTATACCCAATGG & 1194 & $24817-24839$ & {$[47]$} \\
\hline S-AS1 & ACTATCATTTACTGAATTAACAG & BCoV S gene & $25988-26010$ & \\
\hline TORO S5 & GTGTTAAGTTTGTGCAAAAAT & 741 & 20956-20976 & {$[5]$} \\
\hline TORO S3 & TGCATGAACTCTATATGGTGT & BToV S gene & 21677-21697 & \\
\hline
\end{tabular}

${ }^{a}$ Numbering according to the complete genome of BCoV strain Mebus (U00735) and BToV strain Breda 1 (AY427789)

I/08-3 (KF169933), Danish strain DEN03-2 (KF169914), Irish strain RVLC9 (KF272913), Human coronaviruses: HuOC43 (Z32769) and Hu-4408 (L07748; FJ415342). Reference strains of BToV: Breda1 (AY427798), NA7 (AB254073), Gifu-2007TI/E (AB526863), Hokkaido-2008TI/E (AB5268 64), Aichi/2004 (AB526866) and B145 (AJ575373).

\section{Results}

From 101 analyzed fecal and three nasal samples, 82 were positive for $\mathrm{BCoV}$ (78.8\%), and 45 for $\mathrm{BToV}$ (43.2\%). 36 samples were positive for $\mathrm{BRoV}+\mathrm{BCoV} ; 30$ for $\mathrm{BCoV}+\mathrm{BRoV}+\mathrm{BToV} ; 11$ for $\mathrm{BCoV}+\mathrm{BToV}, 4$ for $\mathrm{BRoV}+\mathrm{BToV}$. Five samples were positive for $\mathrm{BCoV}$ only and 11 to BRoV only. From 16 samples chosen for sequencing, 37 sequences were obtained (Table 2). Samples were chosen to cover three-year period.

Table 2 Accession numbers of Croatian BCoV partial N and S and BToV partial $\mathrm{S}$ gene sequences

\begin{tabular}{|c|c|c|c|}
\hline $\begin{array}{l}\text { Isolate } \\
\text { name }\end{array}$ & $\begin{array}{l}\text { BCoV N Accession } \\
\text { no }\end{array}$ & $\begin{array}{l}\text { BCoV S Accession } \\
\text { no }\end{array}$ & $\begin{array}{l}\text { BToV S Accession } \\
\text { no }\end{array}$ \\
\hline B $27 / 10^{a}$ & KM677147 & KM677163 & KM677179 \\
\hline $\mathrm{B} 30 / 10^{\mathrm{a}}$ & KM677148 & KM677164 & \\
\hline $\mathrm{B} 32 / 11^{\mathrm{a}}$ & KM677149 & KM677165 & \\
\hline $\begin{array}{l}\text { B34649/ } \\
11^{\text {a }}\end{array}$ & KM677150 & KM677166 & \\
\hline B3492/11 & KM677151 & KM677167 & KM677182 \\
\hline B37/11 & KM677152 & KM677168 & \\
\hline $\mathrm{B} 6075 / 12^{\mathrm{a}}$ & KM677153 & KM677169 & KM677180 \\
\hline $\begin{array}{l}\mathrm{B} 60853 / \\
11^{\mathrm{a}}\end{array}$ & KM677154 & KM677170 & KM677181 \\
\hline D71/11 & KM677155 & KM677171 & \\
\hline D72/11 & KM677156 & KM677172 & \\
\hline D73/11 & KM677157 & KM677173 & \\
\hline D71-73 F & KM677158 & KM677174 & KM677183 \\
\hline $\mathrm{K} 12 / 10^{\mathrm{a}}$ & KM677159 & KM677175 & \\
\hline $\mathrm{K} 5220 / 12^{\mathrm{a}}$ & KM677160 & KM677176 & \\
\hline $\mathrm{K} 6578 / 11^{\mathrm{a}}$ & KM677161 & KM677177 & \\
\hline K658/10 & KM677162 & KM677178 & \\
\hline
\end{tabular}

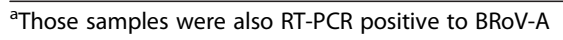

\section{BCoV N gene}

Comparative analysis of the $\mathrm{BCoV} \mathrm{N}$ sequences (nucleotides (nt) 124-485; N protein amino acid (aa) 42-165; I protein aa 21-142) showed that all Croatian strains obtained in 2010-2012 shared a high identity both at the nt level (98-100 \%) and at the deduced $N$ protein aa level (98.3-100 \%). Sequences from eight samples from large dairy farm designated as " $\mathrm{B}$ " in the Eastern region were mutually $100 \%$ identical and most similar to Italian strain 179/07-11 Bubalus (EU019216) and Irish RVLC9 (KF272913) (99,1 \%). Fecal samples designated as " $K$ " and fecal and nasal samples " $D$ " were more similar to human enteric isolates OK-0514-3 and 4408 (FJ415342) (98.8-99.1\%) but phylogenetically clustered with other Croatian strains and to Italian 179/07-11 and Irish RVLC9 (Fig. 1a). The BCoV strains obtained from respiratory and enteric disease did not show any consistent nucleotide differences in the sequenced $\mathrm{N}$ region.

\section{BCoV S gene}

The $\mathrm{BCoV}$ strains obtained from respiratory disease showed two aa differences in the sequenced S1 region: (408 Ser-Ile, 470 Ile-Val).

Comparative analysis of the 975 nt BCoV S sequence (nt 1258-2230; aa 387-710) showed that all Croatian strains shared a high identity both at the nt level (97.7-100 \%) and at the deduced aa level (97.5-100 \%). "K" sequences were identical 98.6-99 \%, "B" 99-100\% and "D" 99.6-100\%.

Our isolates were most similar to Danish strain DEN03-2 (KF169914) (99.1-99.6 \%) and Italian strains Bubalus 179/ 07-11, 438/06-TN and 339/06 (99.0-99.3\%) and were phylogenetically clustered with them (Fig. 1b). On aa level, our isolate K12 were $100 \%$ identical to Danish DEN03-2 (KF169914).

\section{BToV S gene}

Analysis of the $608 \mathrm{nt}$ BToV S sequence (nt 65-671; aa 22-222) showed 93.2-99.8\% identity between our strains at the nt level and 83.7-99.5\% at the deduced aa level (except for the strain B60853/11 that were more divergent). Croatian BToV strains "B" did not show any consistent nt or aa differences in the sequenced $S$ region. They were most similar to Japanese NA-7 (AB254073) (93.4-99.0 \%) 


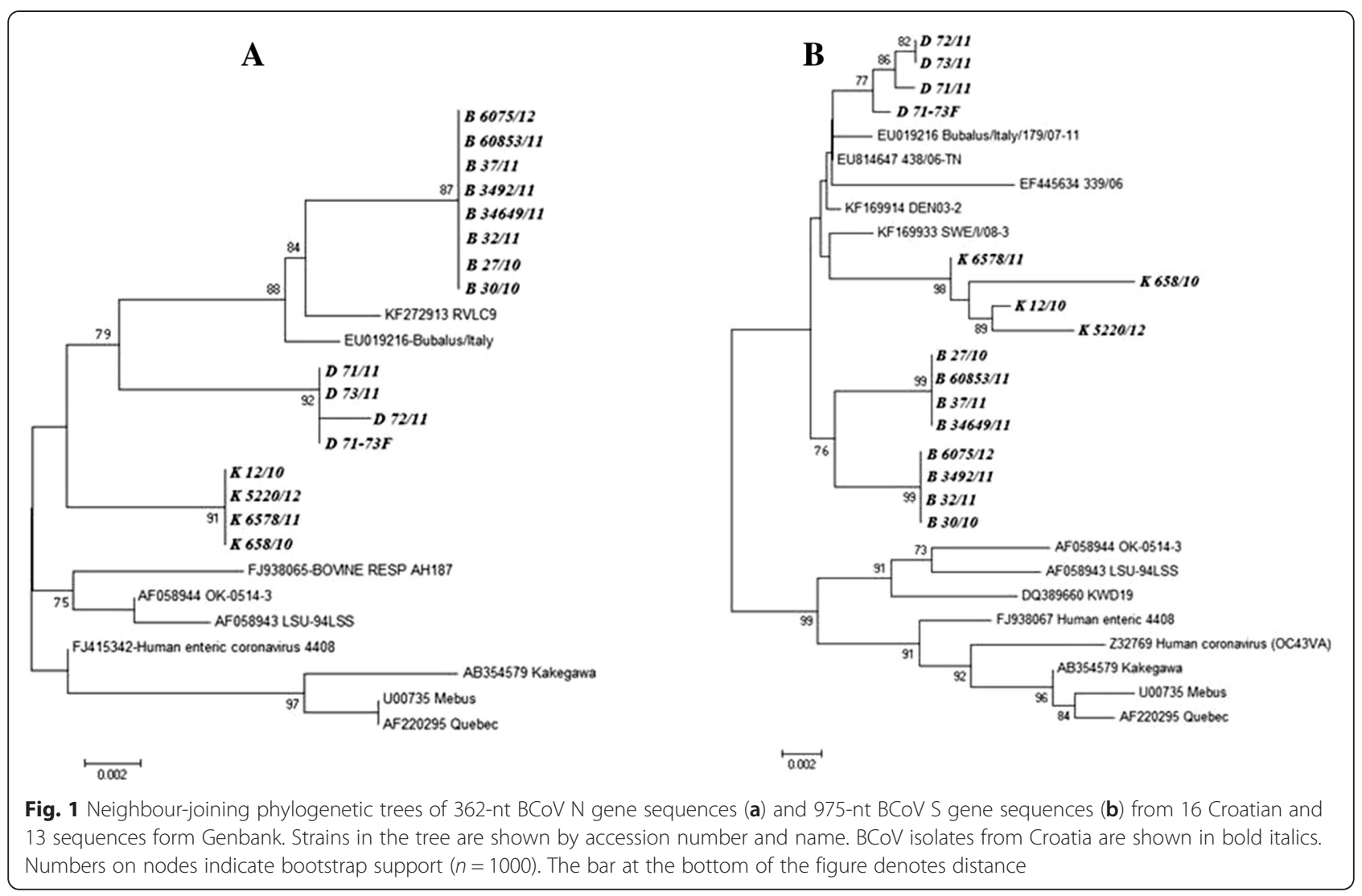

and were phylogenetically clustered with them (Fig. 2). Isolate D71F, obtained from the feces of calf with respiratory symptoms were most identical to Japanese Aichi (96.5\%) and European B145 (96 \%).

\section{Discussion}

This is the first report on the detection of torovirus infection in cattle, as well as molecular characterization of BCoVs and BToVs in Croatia. We determined the partial $\mathrm{N}$ and $\mathrm{S}$ gene sequences of $\mathrm{BCoV}$ and partial $\mathrm{S}$ gene sequences of BToV from i) one large dairy herd during 3-year period ("B"), ii) four small family farms ("K") and iii) paired fecal and nasal samples from calves entered into feedlot ("D"). $\mathrm{BCoV}$ vaccination is not practiced in Croatia.

All Croatian BCoV N and $\mathrm{S}$ gene sequences are clustered together and with sequences from Italy, Denmark and Sweden, separately from the cluster with respiratory strains and the reference strain Mebus (Fig. 1). In this cluster they were further grouped geographically as "B", " $K$ " or " $D$ " subgroup. The similar clustering is obtained when aa sequences for $\mathrm{N}$ and I proteins were analysed (data nor shown). All sequences from the same subgroup were mutually identical when $\mathrm{N}$ gene was analysed. More diversity is recognized when $\mathrm{S}$ gene was analysed, but sequences from large dairy herd ("B") were still 99-100\% identical. This lead to the conclusion that the same $\mathrm{BCoV}$ strain circulated for extended period of time within one herd. In our investigation, we covered the $\mathrm{S}$ region from aa 387-701 which covers the previously reported hypervariable region (aa 452-593) [33, 34] but not the S cleavage site (aa 764-768). Samples obtained from small family farms ("K") showed less mutual identity on S (98.6-99\%) compared with those that came from the same herd ("B").

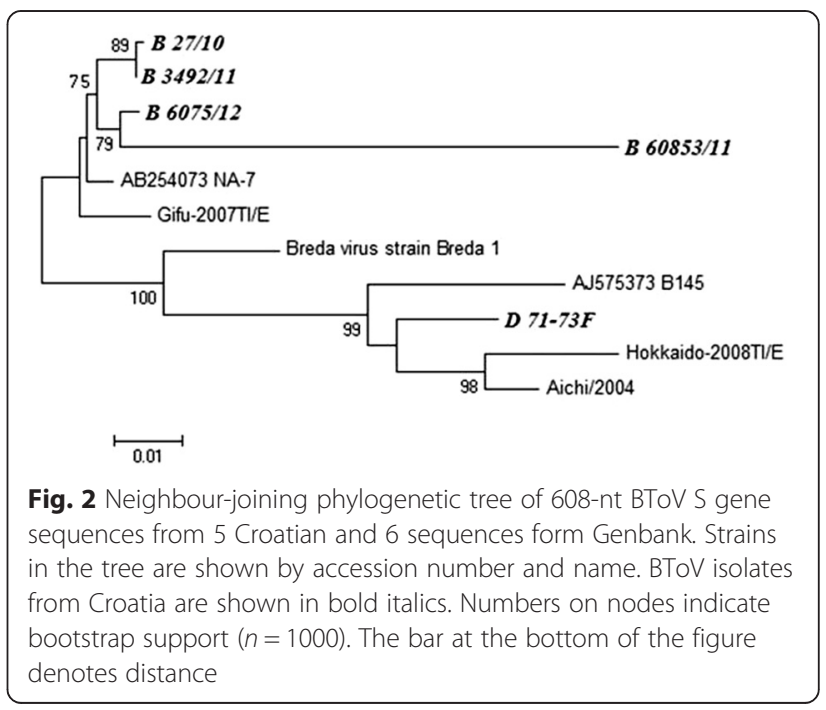


The BCoV strains obtained from respiratory disease showed two aa differences in the sequenced S region: (408 Ser - Ile, 470 Ile - Val), but compared to paired fecal sample, no aa differences and only two nt differences were found. Previous researchers demonstrated that some $\mathrm{BCoV}$ strains isolated from the respiratory tract had different biological, antigenic [35-37] and genetic [38, 39] properties compared with enteric $\mathrm{BCoV}$ strains, whereas others did not detect any consistent differences $[40,41]$ and some suggested that the same strains of $\mathrm{BCoV}$ cause natural outbreaks of respiratory and enteric disease [20, 21, 42, 43]. Our findings, although based on a minimal data are in agreement with the latter fact; there were no differences between respiratory/fecal sample pair. Still, the identified change in amino acid 408 could affect the aa polarity (hydrophilic to hydrophobic).

Regarding the herd designated as " $\mathrm{D}$ ", outbreak of respiratory disease followed soon after entry into a feedlot. Those calves were also RT-PCR positive to BRSV but negative to BHV-1, BPIV-3 and BVDV. Therefore, it was a typical scenario of Bovine respiratory complex (BRC) as a consequence of stress from transport and change in husbandry.

The percentage of $\mathrm{BToV}$ infections in the present study (43.2\%) is higher than that reported in South Korea - 2.9 \% [25], Lower Saxony, Germany-5 \% [44], Japan- 8.4 \% [26], USA- $9.7 \%$ [5] and Canada- $36.4 \%$ [22]. Still, conclusions based on these frequencies are not reliable because this study was not originally planned as an epidemiological study. According to previous study [45], BToV alone has been shown to act as a primary enteric pathogen in cattle. In our study, BToV was found only in co-infection with BCoV and BRV-A (Table 2). It is noteworthy to say that co-infection with $\mathrm{BRoV}-\mathrm{A}$ had not influence on $\mathrm{BCoV}$ and $\mathrm{BToV}$ sequence diversity. Despite the fact that BToV causes diarrhea and respiratory infections in cattle of all ages [6] our isolates from respiratory disease were negative. This also means that respiratory $\mathrm{BToV}$ infection cannot be excluded if more samples has been analysed. Croatian BToVs showed moderate to high degree of nucleotide (87.1-99.8 \%) and amino acid identity (83.7-99.5\%). Comparison of our sequences with one available BToV S gene sequence from Europe (AJ575373) and four sequences from Japan showed high degree of sequence identity (93.4-99.0 \%) between our strains from large dairy farm ("B") and Japanese strain NA-7 (AB254073). On contrary, sequence from feces of calves with respiratory symptoms were more similar to European strain B145 (AJ575373) (96 \%), and Japanese strain Aichi (96.5\%). Phylogenetic analysis revealed that our sequences of BToV S gene from symptomatic animals are more closely related to sequences from Japan than to the Breda 1 strain and European strain (Fig. 2). Still, fecal isolate from herd with respiratory disease clustered with
European and other Japanese strains and was more related to Breda 1 (Fig. 2).

\section{Conclusions}

Despite relatively small number of samples investigated, we can clearly conclude that BCoVs and BToVs (together with rotaviruses) are common enteric pathogens of cattle of all ages and production categories in Croatian herds. Required steps in herd management should include raising awareness of the adequate and timely colostrum intake by the calf as well as vaccination of the cows with one of the commercially available vaccine before calving. Although on minimal data, we have proved that the same $\mathrm{BCoV}$ strain circulated for extended period of time within one herd but different strains circulated in different herds. Molecular characterisation of those viruses revealed some nt and aa differences in relation to reference strains, but generally, Croatian sequences are clustered with other, mainly European BToV and $\mathrm{BCoV}$ isolate sequences.

Competing interests

The authors declare that they have no competing interests.

\section{Authors' contributions}

$\mathrm{IL}$ and NK conceived the study, designed the experiments, performed all the experiments, analyzed the data and drafted the manuscript. IŠ participated in writing the manuscript. TB helped in study design, study implementation and manuscript revision. All the authors have read and approved the final manuscript.

\section{Acknowledgements}

This research was supported by grant No. 048-0481186-1183 from the Ministry of Science, Education and Sports, Republic of Croatia.

Received: 31 March 2015 Accepted: 28 July 2015

Published online: 13 August 2015

\section{References}

1. Cavanagh D. Nidovirales: a new order comprising Coronaviridae and Arteriviridae. Arch Virol. 1997;142:629-33.

2. Lathrop SL, Wittum TE, Brock KV, Loerch SC, Perino LJ, Bingham HR, et al. Association between infection of the respiratory tract attributable to bovine coronavirus and health and growth performance of cattle in feedlots. Am J Vet Res. 2000;61:1062-6.

3. Storz J, Purdy W, Lin X, Burrell M, Truax RE, Briggs RE, et al. Isolation of respiratory bovine coronavirus, other cytocidal viruses, and Pasteurella spp. from cattle involved in two natural outbreaks of shipping fever. J Am Vet Med Assoc. 2000;216:1539-604.

4. Nogueira JS, Asano KM, de Souza SP, Brandão PE, Richtzenhain LJ. First detection and molecular diversity of Brazilian bovine torovirus (BToV) strains from young and adult cattle. Res Vet Sci. 2013;95:799-801.

5. Hoet AE, Smiley J, Thomas C, Nielsen PR, Wittum TE, Saif L. Association of enteric shedding of bovine torovirus (Breda virus) and other enteropathogens with diarrhea in veal calves. Am J Vet Res. 2003:64:485-90.

6. Saif L. Bovine coronavirus infection. In: Coetzer JAW, Tustin RC, editors. Infectious diseases of livestock. Second Edth ed. Oxford, UK: Oxford University Press; 2004. p. 795-802

7. de Vries AAF, Horzinek MC, Rottier PJM, de Groot RJ. The genome organization of the Nidovirales: similarities and differences between arteri-, toro-, and coronaviruses. Semin Virol. 1997:8:33-47.

8. Lai MM, Cavanagh D. The molecular biology of coronaviruses. Adv Virus Res. 1997:48:1-100

9. Senenayake SD, Hofmann MA, Maki JL, Brian DA. The nucleocapsid protein gene of bovine coronavirus is bicistronic. J Virol. 1992;66:5277-83. 
10. Gallagher TM, Buchmeier MJ. Coronavirus spike proteins in viral entry and pathogenesis. Virology. 2001;279:371-4.

11. Kubo H, Yamada YK, Taguchi F. Localization of neutralizing epitopes and the receptor-binding site within the amino-terminal 330 amino acids of the murine coronavirus spike protein. J Virol. 1994;68:5403-10.

12. Yoo D, Deregt D. A single amino acid change within antigenic domain II of the spike protein of bovine coronavirus confers resistance to virus neutralization. Clin Diagn Lab Immunol. 2001;8:297-302.

13. Schultze B, Gross HJ, Brossmer R, Herrler $G$. The $S$ protein of bovine coronavirus is a hemagglutinin recognizing 9-O-acetylated sialic acid as a receptor determinant. J Virol. 1991;65:6232-7.

14. Ballesteros ML, Sanchez CM, Enjuanes L. Two amino acid changes at the $\mathrm{N}$-terminus of transmissible gastroenteritis coronavirus spike protein result in the loss of enteric tropism. Virology. 1997;227:378-88.

15. Jeong JH, Kim GY, Yoon SS, Park SJ, Kim YJ, Sung CM, et al. Detection and isolation of winter dysentery bovine coronavirus circulated in Korea during 2002-2004. J Vet Med Sci. 2005;67:187-9.

16. Liu L, Hägglund S, Hakhverdyan M, Alenius S, Larsen LE, Belák S. Molecular epidemiology of bovine coronavirus on the basis of comparative analyses of the S gene. J Clin Microbiol. 2006;44:957-60.

17. Yoo DW, Parker MD, Babiuk LA. The S2 subunit of the spike glycoprotein of bovine coronavirus mediates membrane fusion in insect cells. Virology. 1991;180:395-9.

18. Park SJ, Jeong C, Yoon SS, Choy HE, Saif $\sqcup$, Park SH, et al. Detection and characterization of bovine coronaviruses in fecal specimens of adult cattle with diarrhea during the warmer seasons. J Clin Microbiol. 2006;44:3178-788.

19. Decaro N, Campolo M, Desario C, Cirone F, D'Abramo M, Lorusso E, et al. Respiratory disease associated with bovine coronavirus infection in cattle herds in southern Italy. J Vet Diagn Invest. 2008;20:28-32.

20. Tråvén $M$, Näslund $K$, Linde $N$, Linde $B$, Silván $A$, Fossum $C$, et al. Experimental reproduction of winter dysentery in lactating cows using BCOV - comparison with BCOV infection in milk-fed calves. Vet Microbiol. 2001;81:127-51.

21. Saif L. Bovine respiratory coronavirus. Vet Clin North Am Food Anim Pract. 2010;26:349-64.

22. Liebler EM, Klüver S, Pohlenz J, Koopmans M. The significance of bredavirus as a diarrhea agent in calf herds in Lower Saxony. Dtsch Tierarztl Wochenschr. 1992;99:195-200 [Article in German].

23. Duckmanton L, Carman S, Nagy E, Petric M. Detection of bovine torovirus in fecal specimens of calves with diarrhea from Ontario farms. J Clin Microbiol. 1998;36:1266-70

24. Matiz K, Kecskeméti S, Kiss I, Adám Z, Tanyi J, Nagy B. Torovirus detection in faecal specimens of calves and pigs in Hungary: short communication. Acta Vet Hung. 2002;50:293-6.

25. Smits SL, Lavazza A, Matiz K, Horzinek MC, Koopmans MP, de Groot RJ Phylogenetic and evolutionary relationships among torovirus field variants: evidence for multiple intertypic recombination events. J Virol. 2003;77:9567-77.

26. Park SJ, Oh EH, Park SI, Kim HH, Jeong YJ, Lim GK, et al. Molecular epidemiology of bovine toroviruses circulating in South Korea. Vet Microbiol. 2008;126:364-71

27. Ito T, Okada N, Fukuyama S. Epidemiological analysis of bovine torovirus in Japan. Virus Res. 2007;126:32-7.

28. Maes RK, Grooms DL, Wise AG, Han C, Ciesicki V, Hanson L, et al. Evaluation of a human group a rotavirus assay for on-site detection of bovine rotavirus. J Clin Microbiol. 2003;41:290-4.

29. Fuchs M, Hubert P, Detterer J, Rziha HJ. Detection of bovine herpesvirus type 1 in blood from naturally infected cattle by using a sensitive PCR that discriminates between wild-type virus and virus lacking glycoprotein. J Clin Microbiol. 1999;37:2498-507.

30. Valentova $V$, Antonis AF, Kovarcik K. Restriction enzyme analysis of RT-PCR amplicons as a rapid method for detection of genetic diversity among bovine respiratory syncytial virus isolates. Vet Microbiol. 2005;108:1-12.

31. Bedeković T, Lojkić I, Lemo N, Čač Ž, Cvetnić Ž, Lojkić M, et al. Genetic typing of Croatian bovine viral diarrhea virus isolates. Vet arhiv. 2012:82:449-62.

32. Tamura K, Stecher G, Peterson D, Filipski A, Kumar S. MEGA6: Molecular Evolutionary Genetics Analysis Version 6.0. Mol Biol Evol. 2013;30:2725-9.

33. Posada D. jModelTest: Phylogenetic Model Averaging. Mol Biol Evol. 2008;25:1253-6.
34. Rekik MR, Dea S. Comparative sequence analysis of a polymorphic region of the spike glycoprotein S1 subunit of enteric bovine coronavirus isolates. Arch Virol. 1994;135:319-31.

35. Yoo D, Parker MD, Babiuk LA. Analysis of the $S$ spike (peplomer) glycoprotein of bovine coronavirus synthesized in insect cells. Virology. 1990;179:121-8.

36. Hasoksuz M, Lathrop SL, Al-dubaib MA, Lewis P, Saif LJ. Antigenic variation among bovine enteric coronaviruses (BECV) and bovine respiratory coronaviruses (BRCV) detected using monoclonal antibodies. Arch Virol. 1999;144:2441-7.

37. Hasoksuz M, Lathrop SL, Gadfield KL, Saif LJ. Isolation of bovine respiratory coronaviruses from feedlot cattle and comparison of their biological and antigenic properties with bovine enteric coronaviruses. Am J Vet Res. 1999;60:1227-33.

38. Lin XQ, Reilly KL O, Storz J, Purdy CW, Loan RW. Antibody responses to respiratory coronavirus infections of cattle during shipping fever pathogenesis. Arch Virol. 2000;145:2335-49.

39. Chouljenko VN, Kousoulas KG, Lin X, Storz J. Nucleotide and predicted amino acid sequences of all genes encoded by the $3^{\prime}$ genomic portion (9.5 kb) of respiratory bovine coronaviruses and comparisons among respiratory and enteric coronaviruses. Virus Genes. 1998;17:33-42.

40. Gelinas AM, Boutin M, Sasseville AMJ, Dea S. Bovine coronaviruses associated with enteric and respiratory diseases in Canadian dairy cattle display different reactivities to anti-HE monoclonal antibodies and distinct amino acid changes in their HE, S and ns4.9 protein. Virus Res. 2001;76:43-57.

41. Reynolds DJ, Debney TG, Hall GA, Thomas LH, Parsons KR. Studies on the relationship between coronaviruses from the intestinal and respiratory tracts of calves. Arch Virol. 1985;85:71-83.

42. Zhang $X$, Herbst K, Kousoulas KG, Storz J. Comparison of the $S$ genes and the biological properties of respiratory and enteropathogenic bovine coronaviruses. Arch Virol. 1994;134:421-6.

43. Niskanen $R$, Lindberg A, Tråvén M. Failure to spread bovine virus diarrhoea virus infection from primarily infected calves despite concurrent infection with bovine coronavirus. Vet J. 2002;163:251-9.

44. Bidokhti MR, Tråvén M, Ohlson A, Baule C, Hakhverdyan M, Belák S, et al. Tracing the transmission of bovine coronavirus infections in cattle herds based on S gene diversity. Vet J. 2012;193:386-90.

45. Aita T, Kuwabara M, Murayama K, Sasagawa Y, Yabe S, Higuchi R, et al. Characterization of epidemic diarrhea outbreaks associated with bovine torovirus in adult cows. Arch Virol. 2012;157:423-31.

46. Tsunemitsu H, Smith DR, Saif LJ. Experimental inoculation of adult dairy cows with bovine coronavirus and detection of coronavirus in feces by RT-PCR. Arch Virol. 1999;144:167-75.

47. Kanno T, Hatama S, Ishihara R, Uchida I. Molecular analysis of the S glycoprotein gene of bovine coronaviruses isolated in Japan from 1999 to 2006. J Gen Virol. 2007;88:1218-24.

\section{Submit your next manuscript to BioMed Central and take full advantage of:}

- Convenient online submission

- Thorough peer review

- No space constraints or color figure charges

- Immediate publication on acceptance

- Inclusion in PubMed, CAS, Scopus and Google Scholar

- Research which is freely available for redistribution 